Przegląd Badań Edukacyjnych Educational Studies Review

ISSN 1895-4308

nr $24(1 / 2017)$, s. 151-172

METODY ZBIERANIA

I ANALIZY DANYCH

W BADANIACH

EDUKACYJNYCH

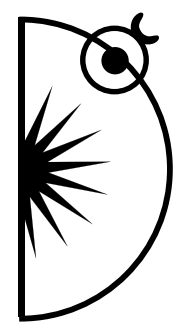

Renata Szczepanik

Wydział Nauk o Wychowaniu, Uniwersytet Łódzki, e-mail: szczepanik@uni.lodz.pl

Andrzej Śliwerski

Instytut Psychologii, Uniwersytet Łódzki, e-mail: andrzej.sliwerski@uni.lodz.pl

\title{
Obietnice bez pokrycia. Etyczne i prawne granice (nie)ujawniania informacji o przestępstwie w badaniach naukowych i psychoterapii
}

DOI: http://dx.doi.org/10.12775/PBE.2017.009

\section{Empty Promises. Ethical and Legal Boundaries of (not)Disclosing Information about Crime in Scientific Research and Psychotherapy}

\begin{abstract}
Performing qualitative research through direct interviews enables researchers to obtain data and information that cannot be obtained in quantitative research. The access to individual conditions of certain attitudes or actions gives a huge opportunity of exploration of various research areas. Each researcher must meet strict ethical standards before committing to the study to prevent harming or exposing the participants. However, the law clearly imposes the need to disclose the knowledge about committed crimes. In this article we will present which specific crimes should be reported according to the Criminal Code. We will also consider whether, in this case, the researcher can provide the participants full anonymity and confidentiality. We also indicate if it is necessary to inform the participants that some content of an interview may be reported to law enforcement agencies and what implications it may have for the conducted research.
\end{abstract}

Key words: qualitative research, anonymity, confidentiality, report of crime, ethics in research. 


\section{Wprowadzenie}

Prowadzenie badań naukowych obwarowane jest wyraźnymi ramami etycznymi wypracowanymi przez różne komisje naukowe. Wszystkie te zasady oparte są na regułach opisanych w Deklaracji Helsińskiej (WMA, 1964). Deklaracja ta ma swoje odzwierciedlenie zarówno w kodeksach towarzystw międzynarodowych, jak i lokalnych. Jednym z najważniejszych celów kodeksów etyki badań jest ochrona badanych oraz kierowanie się ich dobrem. Spisane w nich zasady obligują naukowców do spełniania i przestrzegania określnych standardów, a także kierowania się zasadą nieszkodzenia osobom badanym zarówno na poziomie projektowania badań, ich przeprowadzania, jak i w trakcie upowszechniania rezultatów. Warto również pamiętać, że każde postępowanie badacza musi być zgodne z prawem obowiązującym w danym kraju. Pojawia się jednak ważne pytanie, co zrobić, gdy obowiązujące normy prawne stoją w sprzeczności z zasadami i regułami etyki badań? W kodeksach etycznych szczególny nacisk kładziony jest na konieczność zapewnienia anonimowości, poufności i prywatności osobom badanym. Oznacza to konieczność dochowania tajemnicy zawodowej pozyskanej w związku z wykonywaniem danego zawodu. Istnieją jednakże sytuacje, w których dochodzi do swoistej kolizji norm prawnych i standardów etycznych badacza. Może się zdarzyć, że pod wpływem atmosfery sprzyjającej rozbudowanej i otwartej opowieści o swoim życiu uczestnik badań wyjawi naukowcowi skrywany przed innymi fakt popełnienia przestępstwa. Z podobnymi problemami boryka się psychoterapeuta, który podobnie jak badacz jakościowy z racji wykonywanego zawodu świadomie buduje warunki dla maksymalnej otwartości i szczerości drugiej osoby. W wyniku pozyskania informacji o przestępstwie (ciężkiej rangi) staje jednak przed obowiązkiem zerwania złożonych obietnic poufności informacji i nadużycia zaufania - do czego obliguje go prawo. Konstytucja i przepisy kodeksu karnego są bowiem nadrzędne w stosunku do postanowień kodeksów etycznych.

W artykule wskażemy, w którym miejscu zachodzi między nimi sprzeczność oraz zwrócimy uwagę na specyficzną samotność psychoterapeuty/badacza w procesie podejmowania niektórych decyzji i interpretowania potencjalnych sytuacji (nie)wymagających działań prawnych. Jakie są sytuacje, kiedy normy prawne są nadrzędne w stosunku do etyki badań i podjętego zobowiązania wobec pacjenta/badanego? Czy możliwe jest pogodzenie prawa i poufności tak, by psychoterapeuta/badacz - pacjent/badany nie ponieśli żadnych strat i by sama relacja, a także jakość materiału badawczego/przebiegu terapii nie doświadczyły szwanku? Podejmiemy się próby wykazania niemożności twierdzącej, 
a na pewno jednoznacznej odpowiedzi na tak postawione pytania. Właściwym celem naszych rozważań jest wykazanie trudności (a nawet braku możliwości) pogodzenia norm prawnych i etyczno-moralnych bez konsekwencji dla przebiegu terapii i rzetelności badań naukowych. Tworzenie atmosfery otwartości i szczerości oparte na komunikacie o granicach (prawnych) tychże jest sytuacją nacechowaną paradoksem i sprzyja budowaniu dystansu, a nie specyficznej i koniecznej zażyłości.

Problem prześledzimy, porównując sytuację zawodową psychoterapeuty i naukowca realizującego badania jakościowe. Podobieństwo tych dwóch profesji polega na tym, że w celu osiągnięcia celów zawodowych zarówno psychoterapeuta, jak i badacz jakościowy zachęca osoby, z którymi „pracuje”, do otwartości, buduje atmosferę sprzyjającą bezpieczeństwu i składa (pacjentowi, badanemu) obietnicę poufności danych.

Badacz jakościowy w niniejszym opracowaniu rozumiany jest jako osoba, która gromadząc materiał empiryczny, ,wychodzi zza biurka” i wchodzi w osobiste, bezpośrednie relacje z badanymi (por. Konecki i in., 2012; Męcfal, 2016). Specyficzne dylematy etyczne i moralne towarzyszą przede wszystkim badaczom terenowym, zwłaszcza tym, którzy decydują się na obserwację uczestniczącą ukrytą (por. Cymbrowski, Rancew-Sikora, 2016; Chomczyński, 2006), a szczególnie wtedy, gdy podejmują się trudu łączenia działalności naukowej z aktywnością społeczną w środowisku, które stanowi teren ich badań (np. Surmiak, 2010). O ile bowiem realizując wywiad badacz ma szanse jasno zdefiniować sytuację „wymiany” (por. Wyka, 1990; 1993), to niejawny obserwator nie ujawnia swojej prawdziwej tożsamości, a co za tym idzie - nie powiadamia o swoim badaniu, jego celu i nie ma możliwości doprowadzenia do sytuacji, w której naukowiec zawiera „kontrakt” i informuje o prawach badanej osoby. Problemy te są szczególnie trudne i stanowią treść wielu rozważań i polemik naukowych (por. Chomczyński, 2006; Bielska, 2016; Horolets, 2016).

W opracowaniu skupimy uwagę jedynie na sytuacji badacza prowadzącego projekty jawne i realizującego badania biograficzne (z zastosowaniem takich technik zbierania danych jak wywiady narracyjne czy pogłębione). Trwające często wiele godzin wywiady biograficzne, które przebiegają w określonych fazach i w trakcie których badacz zachęca do otwarcia się, przyjmując niejednokrotnie rolę bezstronnego, ale życzliwego spowiednika, sprzyjają odkrywaniu różnych tajemnic i sekretnych doświadczeń. Uważamy, że więź, jaką nawiązuje badacz z osobą badaną podczas pozyskiwania materiału biograficznego, przypomina w dużej mierze warunki relacji psychoterapeutycznej (choć oczywiście nią nie jest). Badany wyraża zgodę na wywiad i to on decyduje o tym, co powie- 
dzieć - o czym jest zresztą zapewniany na wstępie przez badacza. Naukowiec jasno formułuje komunikat zawierający informację, że jest jedynie gościem badanego i jego prywatnego świata (Kaźmierska 2004; por. Horolets, 2016). Wobec tego prosi go o opowieść „tego co sam zechce” powiedzieć, przekazanie tych informacji, które sam pragnie przekazać. Jeśli badacz zadaje pytania, to zwykle odnosi się do wcześniej podjętych przez narratora wątków, pragnie je pogłębić, zrozumieć, uszczegółowić czy pozyskać argumentację podjętych działań itp. (Kaźmierska, 2004). Do analizy wybraliśmy właśnie taki typ badania, ponieważ to w jego obrębie występuje wysokie ryzyko złamania swoistego kontraktu poufności i lojalności wobec interlokutorów, a badacz skonfrontowany $\mathrm{z}$ informacją o popełnionym przestępstwie zmienia status: z życzliwego spowiednika i zaproszonego do prywatnego świata gościa staje się funkcjonariuszem formalnej kontroli społecznej (bądź się nim nie staje i łamie prawo).

Problemy poruszane w artykule lokować będziemy w szerszej perspektywie dylematów etycznych badań naukowych i relacji psychoterapeutycznej. Stanowią one co prawda przedmiot żywych dyskusji i polemik na łamach zagranicznych opracowań (por. Cymbrowski, Rancew-Sikora, 2016; Bond, 2015), pragniemy jednak ulokować nasze analizy w ramach rodzimych norm prawnych i dlatego - chcąc zachować pewną konsekwencję wywodu - przywoływać będziemy głównie doświadczenia i refleksje polskich naukowców.

\section{Anonimowość, poufność i prywatność w świetle polskich uregulowań prawnych}

Konstytucja Rzeczpospolitej Polskiej (1997) zapewnia każdemu obywatelowi prawo do prywatności i jej ochrony. Artykuł 47 Konstytucji stanowi, że „Każdy ma prawo do ochrony prawnej życia prywatnego, rodzinnego, czci i dobrego imienia oraz do decydowania o swoim życiu osobistym". Artykuł 51 stanowi zaś, że „Nikt nie może być obowiązany inaczej niż na podstawie ustawy do ujawniania informacji dotyczących jego osoby”, co oznacza prawną ochronę danych osobowych. Ich przetwarzanie może odbywać się tylko i wyłącznie na podstawie i w granicach określonych przez obowiązujące akty prawne.

Regulacje prawne dotyczące złamania tajemnicy zawodowej zostały umieszczone w Kodeksie karnym (1997). W rozdziale XXXIII „Przestępstwa przeciwko ochronie informacji” art. $266 \S 1$ stanowi: „Kto, wbrew przepisom ustawy lub przyjętemu na siebie zobowiązaniu, ujawnia lub wykorzystuje informację, z którą zapoznał się w związku z pełnioną funkcją, wykonywaną pracą, działalnością publiczną, społeczną, gospodarczą lub naukową podlega 
grzywnie, karze ograniczenia wolności albo pozbawienia wolności do lat 2" ze wskazaniem, że ściganie tego przestępstwa następuje na wniosek osoby pokrzywdzonej. Kodeks karny określa wyraźnie konieczność dochowania tajemnicy zawodowej, również tej, którą pozyskaliśmy w ramach działalności naukowej. Kodeks Postępowania Karnego (1997) w artykule 180 § 1 uznaje, że osoby zobowiązane do dochowania tajemnicy zawodowej mogą odmówić zeznań co do okoliczności, na które rozciąga się ten obowiązek, ale sąd lub prokurator mogą je z tego obowiązku zwolnić. Polski system prawny dopuszcza więc możliwość ujawnienia informacji niezbędnej dla wymiaru sprawiedliwości w trakcie postępowania karnego lub przygotowawczego. Dotyczy to jednak sytuacji, w której postępowanie wobec danej osoby już się toczy. Co zrobić, gdy informacja o popełnionym przestępstwie pojawia się w trakcie kontaktu objętego zasadą poufności? W jakiej sytuacji prawnej pozostaje psychoterapeuta oraz badacz? Czy jest zobowiązany do poinformowania organów ścigania o możliwości popełnienia przestępstwa?-

Kodeks karny (1997) w rozdziale „Przestępstwa przeciwko wymiarowi sprawiedliwości” w art. $240 \S 1$ stanowi, że kto mając wiarygodną wiadomość o karalnym przygotowaniu albo usiłowaniu lub dokonaniu czynu zabronionego lub przestępstwa o charakterze terrorystycznym, nie zawiadamia niezwłocznie organu powołanego do ścigania przestępstw, podlega karze pozbawienia wolności do lat 3 . Artykuł ten nie dotyczy osób, które są ofiarami; zapobiegły popełnieniu danego czynu; albo zaniechały zawiadomienia z obawy przed odpowiedzialnością karną grożącą jemu samemu lub jego najbliższym. Warto zwrócić uwagę na wymienione w tym artykule „czyny zabronione”. Należą do nich: eksterminacja ludności (art. 118 k.k.), zamach stanu (art. 127 k.k.), usunięcie przemocą konstytucyjnego organu Rzeczypospolitej Polskiej (art. 128 k.k.), działalność na rzecz obcego wywiadu (art. 130 k.k.), przestępstwa przeciwko obronności mające na celu osłabienie mocy obronnej Rzeczypospolitej Polskiej (art. 140 k.k.), zabójstwo (art. 148 k.k.), spowodowanie niebezpieczeństwa katastrofy (art. 163 k.k.), przejęcie kontroli nad statkiem wodnym lub powietrznym (art. 166 k.k.) oraz porwanie i przetrzymywanie zakładnika (art. 252 k.k.). Nowelizacja kodeksu karnego z 2017 roku (Dz.U. z 2017 r., poz. 768) uzupełnia listę tych czynów o: doprowadzenie do ciężkiego uszczerbku na zdrowiu (art. 156 k.k.), gwałt ze szczególnym okrucieństwem, gwałt zbiorowy, gwałt na osobie poniżej $15 \mathrm{r}$.ż. oraz gwałt na osobach z najbliższej rodziny (art. 197 § 3 i 4 k.k.), wykorzystanie seksualne osób upośledzonych lub chorych psychicznie (art. 198 k.k.) oraz obcowanie płciowe z osobami poniżej 15 r.ż. (art. 200 k.k.). 
Kodeks karny w artykule $240 \S 1$ literalnie powołuje się tylko i wyłącznie na te typy czynu zabronionego. Wobec każdego innego czynu przestępczego trzeba odnosić się do Kodeksu Postępowania Karnego (1997). Art. $304 \S 1$ k.p.k. stanowi, że „kto dowiedziawszy się o popełnieniu przestępstwa ściganego z urzędu ma społeczny obowiązek zawiadomić o tym prokuratora lub policję". Społeczny obowiązek oznacza, że ma on charakter moralny, a nie prawny. Za niezgłoszenie takiego przestępstwa kodeks karny nie przewiduje żadnych sankcji. Gardocki (1998) wskazuje, że obowiązek zawiadomienia o przestępstwie z art. $240 \S 1$ k.k. uchyla zarówno tajemnicę dziennikarską, określoną na mocy prawa prasowego (1984), jak i tajemnicę lekarską określoną w Ustawie o zawodzie lekarza (2002).

\section{Ujawnienie informacji o przestępstwie w trakcie psychoterapii}

Granice tajemnicy zawodowej i poufności w warunkach psychoterapii opisane są w wielu kodeksach i publikacjach. Przyjrzenie się rozwiązaniom zaproponowanym w tym obszarze może znacznie ułatwić rozstrzygnięcie dylematu informowania o popełnieniu przestępstwa w trakcie badań jakościowych. Warto jednak na początku podkreślić, że zdaniem wielu autorów „sprawa nie jest do końca nie tylko prawnie uregulowana, ale także przemyślana i przedyskutowana w środowisku psychoterapeutycznym" (Toeplitz-Winiewska, 2009b, s. 249).

W literaturze światowej możemy znaleźć wiele wytycznych dotyczących warunków naruszenia poufności. W Standards and Ethics for Counselling in Action Bond (2015) wskazuje, że naruszając tajemnicę zawodową, terapeuta musi ocenić:

- prawdopodobieństwo, że przestępstwo może być popełnione,

- stopień zagrożenia,

- nieuchronność wystąpienia przestępstwa,

- efektywność zgłoszenia, czyli stopień, w którym jest w stanie zapobiec popełnieniu danego przestępstwa.

Wytyczne brytyjskiego wydziału zdrowia wskazują, że psycholog ma prawo naruszyć zasadę poufności, gdy zostało popełnione lub pacjent nosi się z zamiarem popełnienia poważnego przestępstwa (Department of Health, 2003). Za poważne przestępstwo uznano morderstwo, gwałt, zdradę stanu, porwanie oraz przemoc wobec dzieci. Są to jednak wytyczne umieszczone w innym systemie prawnym, co oznacza, że nie można ich literalnie przenieść na grunt polski.

Polski kodeks etyczno-zawodowy psychologa w punkcie 21 określa, że „psychologa obowiązuje przestrzeganie tajemnicy zawodowej. Ujawnienie 
wiadomości objętych tajemnicą zawodową może nastąpić jedynie wtedy, gdy poważnie zagrożone jest bezpieczeństwo klienta lub innych osób" (PTP, 1991). Punkt ten opiera się na przepisach prawa wspomnianych wcześniej art. 240 $\S 1$ k.k. oraz art. $162 \S 1$ k.k. Ten drugi określa konieczność udzielenia pomocy osobie znajdującej się w sytuacji grożącej bezpośredniemu niebezpieczeństwu utraty życia lub zdrowia. Oznacza to, że można złamać obowiązującą tajemnicę zawodową jedynie w przypadku przestępstw wymienionych w artykule 240 $\S 1$ k.k. lub w przypadku realnej groźby samobójstwa.

Problem jest jednak bardziej złożony, jeśli zagrożenie dotyczy dziecka. Ustawa o przeciwdziałaniu przemocy w rodzinie (2005) w art. 12.1 stanowi, że osoby, które w związku z wykonywanym zawodem mają uzasadnione podejrzenie o popełnieniu przestępstwa z użyciem przemocy w rodzinie, mają obowiązek niezwłocznego poinformowania o tym policji lub prokuratora. Art. 9d tej samej ustawy uznaje, że zgłoszenie nie wymaga zgody osoby dotkniętej przemocą. Konieczność zawiadomienia organów ścigania obowiązuje nawet wtedy, gdy informacja jest przekazana przez członka rodziny lub osobę będącą świadkiem tej przemocy. Zgodnie z tym przepisem, powzięcie informacji o krzywdzie dziecka obliguje terapeutę do zgłoszenia tego faktu organom ścigania, a co za tym idzie, zwalnia go z obowiązku utrzymania tajemnicy zawodowej. Kiembłowski (2005, s. 162) wskazuje nawet, że mamy do czynienia $\mathrm{z}$,bezwzględnym obowiązkiem poinformowania policji lub prokuratury o podejrzeniu popełnienia przestępstwa, którego ofiarą jest dziecko". Czy to oznacza, że w przypadku innych przestępstw niewymienionych w art. $240 \S 1$ k.k. postępowanie może wyglądać podobnie? Odpowiedź brzmi nie. Za przykład mogą posłużyć przestępstwa przeciwko wolności seksualnej. Od 2014 roku przestępstwo zgwałcenia (art. 197 § 1-4 k.k.) jest ścigane z urzędu, a nie jak wcześniej, na wniosek osoby pokrzywdzonej. Nowelizacja kodeksu karnego z 2017 roku (Dz.U. z 2017 r., poz. 768) uznaje konieczność zawiadomienia organów ścigania jedynie w przypadku takiego gwałtu, który oznaczony jest przez ustawodawcę cechami szczególnego okrucieństwa, gwałtu zbiorowego i na osobach z najbliższej rodziny. Obowiązek zgłoszenia obejmuje również przestępstwa o charakterze seksualnym na osobach małoletnich. Posiadanie wiarygodnej informacji o dokonanym gwałcie nie zawsze stanowi więc okoliczność, która zwalnia psychologa z zasady dochowania poufności. Dodanie w nowelizacji kodeksu karnego tylko części przestępstw przeciwko wolności seksualnej sprawia, że psycholog sam musi dokonać oceny charakteru gwałtu. Jest to o tyle trudne, że w orzecznictwie przyjmuje się, iż zgwałcenie jest szczególnie okrutne, gdy: ,a) wyrządza znaczną dolegliwość fizyczną lub powoduje 
poważne następstwa w psychice ofiary; b) sprawca stosuje środki, których intensywność jest nadmierna w stosunku do stawianego przez ofiarę oporu; c) sprawca przedsiębierze działania mające na celu nie tylko zbliżenie płciowe, ale i zmierza do poniżenia ofiary; d) sprawca działa w sposób drastyczny, odrażający czy wyjątkowo brutalny; e) ofiara cechuje się szczególnymi właściwościami: młody lub starczy wiek, nieporadność życiowa, zaawansowana ciąża, choroba itp." (SA, 2010). Psycholog, który zastanawia się, czy jest zwolniony z obowiązującej go tajemnicy zawodowej, nawet jeśli dobrze zna obowiązujące prawo, pozostaje samotny $\mathrm{w}$ interpretowaniu charakteru dokonanego gwałtu. Zła ocena czynu może go narazić na zarzut bezprawnego ujawnienia tajemnicy zawodowej.

Psychologa/terapeutę obowiązują również przepisy zawarte w Ustawie o ochronie zdrowia psychicznego (1994). W art. 51 znajduje się wskazanie, że w dokumentacji „dotyczącej badań lub przebiegu leczenia osoby, wobec której podjęto czynności wynikające z niniejszej ustawy, nie utrwala się oświadczeń obejmujących przyznanie się do popełnienia czynu zabronionego". Art. 52.1 stanowi zaś, że „nie wolno przesłuchiwać osób obowiązanych do zachowania tajemnicy jako świadków na okoliczność przyznania się przez nią do popełnienia czynu zabronionego". Zgodnie z postanowieniem Sądu Najwyższego (z dnia 20 kwietnia 2005 r., I KZP 6/05) art 52.1 obejmuje również psychologów. Sąd Najwyższy w swoim postanowieniu dodaje, że zarówno sąd karny, jak i prokurator nie mogą zwolnić psychologa z tajemnicy zawodowej na mocy art. 180 k.p.k., nawet jeśli psycholog wyrazi gotowość ujawnienia tej tajemnicy. Oczywiście odnosi się to tylko i wyłącznie do zeznań dotyczących przyznania się klienta do winy w trakcie prowadzonej terapii. Jeśli więc klient przyzna, że dokonał gwałtu, psycholog nie tylko nie może tego zapisać w dokumentacji, ale nie może również zeznawać na tę okoliczność, nawet jeśli był to gwałt noszący znamiona szczególnego okrucieństwa. Opisywane przepisy obejmują bowiem przestępstwa określone w art. $240 \S 1$ k.k. Jeśli klient przyzna się do popełnienia zbrodni lub poinformuje o takim zamiarze, psycholog ma obowiązek zawiadomić o podejrzeniu przestępstwa, ale w trakcie postępowania nie będzie mógł być przesłuchiwany na okoliczność przyznania się klienta do winy. Status prawny psychologa jest identyczny do statusu, jaki posiada pełnomocnik (adwokat) czy też duchowny. W ich przypadku również ustanowiono zakaz przesłuchiwania na okoliczność przyznania się do winy (art. 178 k.p.k.), który nie zwalnia ich z konieczności zawiadomienia o najcięższych zbrodniach (Żylińska, 2015). 


\section{Cele i warunki budowania klimatu zaufania: cechy wspólne i różnice psychoterapii i badań jakościowych}

W ostatnich latach w polskim piśmiennictwie dedykowanym zagadnieniom badań jakościowych obserwuje się wzrost zainteresowania zagadnieniami etyki. Co więcej, etyczne ugruntowanie metodologii kontaktu badacza jakościowego $\mathrm{z}$ badanym jest przedmiotem autorefleksji naukowców z wyraźnym odniesieniem omawianych problemów do płaszczyzny kontaktu psychoterapeutycznego (por. Golczyńska-Grondas, Grondas, 2013; Niedbalski, 2013).

Nieprzypadkowo zagadnienie granic poufności i dylematów etyczno-prawnych można rozpatrywać, zestawiając relację osobową, jaką tworzą psychoterapeuci i badacze jakościowi z osobami znajdującymi się w kręgu ich „oddziaływań” w ramach wypełniania przez nich zadań wynikających z ról zawodowych. Naszym zdaniem relacje te są podobne, choć inne są ich założone cele.

Co łączy psychoterapeutów i badaczy? Niewątpliwie są to: 1) osobista i bliska relacja, jaką nawiązują z drugą osobą w celu osiągnięcia swoich celów, 2) budowanie atmosfery sprzyjającej otwartości i szczerości, 3) przejawiana życzliwość i empatia oraz 4) składane obietnice poufności, a także 5) wysoka świadomość etyki zawodowej.

Po pierwsze zarówno psychoterapeuta, jak i badacz jakościowy zachęca swojego interlokutora do maksymalnego otwarcia się. Zawiera z nim swoisty kontrakt polegający na tym, że rozmówca będzie mówił szczerze o swoim życiu. Dążenie badacza do sytuacji, w której badany „otwiera się”, to troska o pozyskanie wartościowego, wielowątkowego i rozbudowanego wywiadu. $\mathrm{Na}$ jakość materiału biograficznego pozyskiwanego tą drogą mają wpływ różne czynniki. Do najważniejszych należą określone kompetencje badacza i samego badanego. Badacz przede wszystkim sam jest „narzędziem badania” przez stworzenie warunków sprzyjających nieskrępowanej presją czasu czy miejsca narracji, a także jest życzliwym i aktywnym słuchaczem (głównie komunikuje swoje zainteresowanie opowieścią mową ciała).

W przypadku badanego można mówić o specyficznej łatwości (lub jej braku) w sposobie opowiadania. Mówi się wtedy o tzw. podatności narracyjnej osoby (zob. Kaźmierska, 2004). Narrator stara się zatem, by jego opowieść była spójna, miała swój początek i koniec, a poruszane wątki układały się w logiczną i wiarygodną całość. To między innymi dlatego opisując pewne doświadczenia, zgodnie z naturalnym przymusem uwiarygodnienia swojego wywodu, stara się wpleść w narrację jak najszerszy kontekst przedstawianego procesu, tak by badacz miał szansę zrozumieć zarówno motywację i dynamikę rozwoju 
wydarzeń, jak i wpływ czynników (przypadkowych i nieprzypadkowych) na ostateczny obraz prezentowanych zjawisk (Schütze, 1992; Kaźmierska, 2004; Szczepanik, Siebert, 2016). Często pod wpływem swoistego „przymusu” uwiarygodniania swojej narracji sygnalizuje wydarzenia, których nie miał w planie ujawniać ${ }^{1}$. Atmosfera „kontraktu” sprzyja takiemu otwarciu dzięki zapewnieniu badacza o poufności i dyskrecji.

Podobnie wygląda to $\mathrm{w}$ przypadku relacji psychoterapeutycznej. Terapeuta, zapewniając warunki anonimowości, akceptacji i zrozumienia, pozwala klientowi na to, aby ten w pełni otworzył się przed nim, opowiadając o swoim problemie i jego potencjalnych źródłach.

Różnice pomiędzy tymi dwoma zawodami są oczywiste (przede wszystkim inne cele zawodowo-społeczne), jednakże z punktu widzenia problematyki podjętej w opracowaniu należy zwrócić uwagę na jeden element. Jest nim sposób docierania do osób, którym składane są obietnice poufności. Psychoterapeuta zawiera swoisty kontrakt o poufności z osobą, która sama zgłasza się do niego o pomoc, a badacz jakościowy sam „wprasza się” do życia prywatnego osoby badanej. Warto także zauważyć, że badacz nie podlega pod ustawę o ochronie zdrowia psychicznego, a tym samym nie będzie mógł nigdy skorzystać z prawa nieudzielania informacji o przyznaniu się do winy.

\section{Granice jawności i poufności. Dylematy badacza jakościowego}

W piśmiennictwie naukowym analizowany jest problem angażowania badacza w relacje z osobami badanymi, a nawet „zaprzyjaźniania się” z nimi i granic zażyłości (Fatyga, 2013; Nowicka, 2016; Horolets, 2016), technik zdobywania zaufania w badanym środowisku (np. Kleszcz, 2004), stawania się „swojakiem” wśród badanych, a następnie ujawniania prawdziwej tożsamości (Chomczyński, 2006; Bielska, 2016), niwelowania nierówności społecznej w kontaktach z wykluczonymi społecznie i ,nosicielami” piętna (Kuźma, 2013; Ślęzak, 2013; Witkowski, 2016) czy w końcu dylematy związane z byciem rzecznikiem badanej grupy (m.in. Szczepanik, 2015; 2017). Lista problemów towarzyszących badaczom terenowym jest długa (por. Cymbrowski, Rancew-Sikora, 2016) i nie znajdują oni odpowiedzi na wszystkie nurtujące ich pytania w dokumentach stanowiących opis postępowania etycznego. Zasadnicza część zasad w kodeksach etycznych odnosi się bowiem do organizowania badań i obchodzenia się

${ }^{1}$ Doświadczenia takie miała jedna $\mathrm{z}$ autorek opracowania podczas prowadzenia badań biograficznych z udziałem wielokrotnych przestępców (zob. Szczepanik, 2015). 
z danymi pozyskanymi z wywiadów kwestionariuszowych, a nie bliskich i osobistych relacji, jakie nawiązuje badacz jakościowy w terenie w celu zdobycia wartościowego materiału empirycznego. Na dylematy tej natury zwracają uwagę wszyscy badacze tzw. trudnych terenów badań (m.in. Kuźma, 2013). Problem ten trafnie oddają słowa Chomczyńskiego, który realizował trwające wiele miesięcy badania w instytucjach resocjalizacyjnych: „Badacz w niewielu tylko przypadkach może liczyć na wskazówki odnoszące się do etyki pracy badawczej, gdyż trafia do środowiska, które nie jest dla niego naturalne, w związku z czym często stosowane przez niego heurystyki zawodzą i jest zmuszony liczyć na własny osąd sytuacji”" (Chomczyński, 2014, s. 73). Dylemat ten staje się bardziej problematyczny, jeśli weźmie się pod uwagę to, że osąd danej sytuacji może być obwarowany przepisami prawa, a podjęta przez badacza decyzja o zachowaniu poufności może sprawić, że będzie on odpowiadał karnie za zatajenie informacji o popełnieniu konkretnego przestępstwa.

Badacz jakościowy - szczególnie tzw. trudnych środowisk (np. osób notorycznie łamiących normy) - w sposób szczególny narażony jest na dokonywanie trudnych wyborów i rozstrzyganie dylematów etycznych. W jego działalność wpisuje się nie tylko konieczność rozwiązywania problemów tak, by unikać kolizji norm etycznych i prawnych, ale także powinien on posiadać kompetencje przewidywania i zapobiegania ich pojawiania się (np. punkt 7 , 10 i 19 kodeksu etyki socjologa; por. Galewicz, 2009). Oznacza to sytuację, w której kierowany dociekliwością i mimo realnych szans na osiągnięcie trudnych celów naukowych powinien rozważyć stosowność kontynuowania swoich działań z uwagi na możliwość wystąpienia konfliktu ról i powinności etycznych czy prawnych (w odniesieniu do badanego i społeczeństwa). W trosce o ochronę badanego badacz może zapobiegać sytuacji ujawniania przez niego informacji o przestępstwie, gdy dynamika badania (np. emocje towarzyszące rekonstruowanym doświadczeniom) powoduje specyficzne osłabienie kontroli wypowiedzi u badanego. Doświadczenia własne jednej z autorek opracowania dowodzą takich sytuacji. W trakcie wywiadu z recydywistami (zob. Szczepanik, 2015) niejednokrotnie intuicyjnie przerywała wywód pytaniem odbiegającym od głównego nurtu wypowiedzi, nie dopuszczając w ten sposób do zakończenia przez badanego „ryzykownego” wątku. Niestety nie pozostawało to bez znaczenia dla wartości pozyskiwanego materiału. Zmieniała się dynamika wywiadu, uruchamiało to czujność i dezorientację u badanych. Kilkukrotnie zdarzyło się, że badaczka została poproszona o wyłączenie na chwile dyktafonu i zapowiedź, że zostaną przekazane jej informacje szczególnie poufne tylko do jej wiadomości, które rzucą ważne światło na uwarunkowania opisywanych 
wydarzeń. W obronie przed koniecznością konfrontacji z potencjalnie trudną sytuacją etyczno-prawną formułowała komunikat: jeśli coś się nie nadaje do nagrania, to proszę mi tego nie mówić wcale. Badani zmieniali zupełnie temat i już nie wracali do wątków rozpoczętych przed skierowaną prośbą o wyłączenie dyktafonu. Autorka jest świadoma tego, że w ten sposób straciła szanse na uzyskanie interesującego materiału, a także zdekonstruowała definicję nieformalnej atmosfery badania i nadwerężyła mozolnie budowane warunki poufności i dyskrecji. Sytuację tę w dużej mierze ilustruje wniosek sformułowany przez Horolets (2016, s. 58), która odnosząc się do niejednoznacznego statusu i roli badaczy antropologów, pisała: „Jedna z tych szarych stref to nieostra granica między tym, co zawodowe, a tym, co osobiste".

Najważniejszy z punktu widzenia problematyki opracowania jest problem tajemnicy zawodowej. Nie ma wątpliwości co do tego, że naukowca „obowiązuje tajemnica co do tożsamości uczestników badania oraz konkretnych danych uzyskanych od każdego z nich" (Toeplitz-Winiewska, 2009a, s. 95). Uznaje się, że projekt badawczy gwarantuje badanym anonimowość tylko wtedy, gdy zarówno osoby zapoznające się z wynikami badań, jak i osoby je przeprowadzające nie mają możliwości identyfikacji autorów poszczególnych wypowiedzi (Brzeziński, 2009). Tak rozumianej anonimowości nie można zapewnić we wszystkich badaniach. Trudno bowiem spełnić te warunki w sytuacji prowadzenia projektów badań jakościowych ${ }^{2}$, a jeszcze trudniej, jeśli mają one charakter badań terenowych. Trudno żądać od badacza, który przeprowadza wywiad $\mathrm{z}$ osobą badaną, by udawał, że nie jest w stanie jej zidentyfikować. Ponadto dane pochodzące $\mathrm{z}$ badań jakościowych mają charakter osobisty, nacechowane są indywidualizmem doświadczeń, a rygorystyczna anonimizacja bohaterów (także miejsc, wydarzeń itp., które się z nim łączą) może znacząco zniekształcić charakter informacji i uniemożliwić ich reanalizę (Straczuk, Filipkowski, 2014; Andrejuk, 2014; Kaźmierska, 2014). Przykładowo, pełna anonimizacja danych dokonana przez badacza po realizacji wywiadu utrudniać może znacząco ich analizę i interpretację wtedy, jeśli naukowiec opracowuje wyniki badań

${ }^{2}$ Problem ten opisuje K. Kaźmierska (2014, s. 227): „(...) nie zawsze zakrycie tożsamości jest możliwe w dobie powszechnie dostępnych informacji. Często niepozorny szczegół w biografii badanego umożliwia znalezienie takiej osoby w Internecie. Z kolei całkowita zmiana szczegółów pozbawia materiał niezbędnego kontekstu znaczeniowego i empirycznie go wyjaławia (...). Można też wyobrazić sobie sytuację, iż badacz zmieniając szczegóły dostosowuje je do aktualnej wiedzy kulturowej i kontekstu społecznego, ten jednak z czasem może się zmienić i być dla kolejnych badaczy podejmujących reanalizę nieczytelny, a więc zagubiona zostanie paralelność między rzeczywistym detalem a dokonaną anonimizacją". 
w zespole. W takim wypadku możemy mówić jedynie o poufności, która oznacza obietnicę nieujawniania informacji o respondencie w sposób, który umożliwiłby jego rozpoznanie przez osoby nieangażowane bezpośrednio w badania naukowe.

Kwestia zapewnienia jedynie poufności danych jest szczególnie istotna w przypadku badania grup, które $\mathrm{z}$ reguły łamią normy prawne i obyczajowe (np. wielokrotni przestępcy, osoby prostytuujące się). Naturalnie stosunek tych badanych do badacza nacechowany jest wysoką dozą dystansu i nieufności. $\mathrm{W}$ ich interesie jest zatajanie pewnych informacji, zwłaszcza tych, które mogą stwarzać ryzyko dotarcia do sprawców przestępstwa czy odkrycia „tajników wiedzy" ich działalności dewiacyjnej przez przedstawicieli formalnej kontroli społecznej. A to często owe sekrety są interesujące dla naukowca, ponieważ stanowią one o specyfice świata społecznego, w który próbuje wniknąć. Badacz jest osobą z gruntu podejrzaną jako reprezentant tzw. normalnego społeczeństwa (Szczepanik, 2015), choć potencjalnie „przydatną” (Miszewski, 2007). Jego właściwościom społecznym narzuca się bowiem dwa znaczenia. Oba związane są z nadaniem badaniom naukowym narzędzia formułowania opinii wartościujących: badacz zbiera dane, a następnie je analizuje i wysuwa odpowiednio wnioski na ich podstawie. $Z$ jednej strony zachodzi obawa przed ujawnieniem sekretów, z drugiej jednak budzi się nadzieja, że naukowiec stanie się mecenasem pokrzywdzonych (przez prawo, instytucje, system, społeczeństwo).

Badacz tzw. środowisk trudnych, wymagających, wchodząc w bezpośrednie relacje z różnymi osobami i grupami społecznymi, powinien opierać je na zasadach i normach etycznych gwarantujących poszanowanie godności oraz praw jednostek i grup. Ma obowiązek chronić interesy osób, które są bohaterami jego prac. To właśnie gwarancja dyskrecji pozwala nawiązać z badanym (podobnie jak psychoterapeucie z pacjentem) relację opartą na zaufaniu, szczerości i lojalności, dzięki czemu można pozyskać wartościowy materiał empiryczny dla analiz lub niezbędny dla postawienia diagnozy czy przeprowadzenia terapii. Dlatego też przedstawiciele zawodów, których wspólnym mianownikiem jest zobowiązanie do dyskrecji, przywiązują dużą wagę do ochrony pozyskanych informacji. Zagadnienia etyki badacza jakościowego stają się pierwszoplanowe (Rancew-Sikora, Cymbrowski, 2016) i jak podkreśla Wyka (1990), szczególna odpowiedzialność moralna spoczywa na nim właśnie dlatego, że to on inicjuje kontakt.

Czy zapobieganie konfliktowi prawa (powinności wobec systemu prawno-społecznego) i etyki (lojalności wobec badanego) jest możliwe? Przykładowo punkt 10 kodeksu etyki socjologa stanowi, że naukowcy powinni zadbać o to, by 
nie udzielać gwarancji poufności, których nie mogą dotrzymać. Sprawa wydaje się prosta i jasna na poziomie formułowania zaleceń postępowania etycznego, jednak komplikuje się w przypadku, gdy badacz podejmuje wysiłki i starania na rzecz budowania klimatu nacechowanego otwartością i szczerością. Budowanie takiego klimatu wymaga bowiem nawiązania $\mathrm{z}$ badanym relacji nieformalnych, tj. nieopartych na formalnej asymetrii ról społeczno-zawodowych. Niesymetryczność ta wynika przede wszystkim z celu oraz korzyści będących udziałem badania.

Cele naukowca są oczywiste. Jego intencjom przyświeca chęć pozyskania danych empirycznych, w oparciu na których będzie mógł wnieść wkład do określonego fragmentu wiedzy naukowej o interesującym zjawisku. Motywy, jakimi się kieruje badany, wyrażając zgodę na badania, mogą być różne. Mogą one być prozaiczne, jak zwykła ciekawość czy zabawa ${ }^{3}$. O wiele częściej jednak wynikają z chęci bycia „teoretykiem swojego życia”, ekspertem czy z poczucia misji, jaką badany może spełnić wobec nauki czy społeczeństwa w ogóle 4 . W piśmiennictwie naukowym opisywane są również motywy wyrażania zgody na udział w badaniach, które wynikają z nadziei na zwrócenie uwagi na problemy, jakie są udziałem samych badanych czy też grup, których są reprezentantami. W tym przypadku badany ma nadzieję zabrania głosu „w swojej sprawie", pokazania indywidualnej perspektywy trudności życiowych - zwłaszcza jeśli boryka się z potępieniem społecznym czy marginalizacją (zob. Miszewski, 2007; Szczepanik, 2017) oraz kiedy w badaniach upatruje możliwość „ukazania lepszej twarzy" grupy społecznej, której jest uczestnikiem (Horolets, 2016, s. 61).

Badacz jakościowy dąży do tego, by relacja, jaką nawiązuje z badanym, przypominała naturalne, spontaniczne spotkanie się dwóch (lub więcej) osób, któremu towarzyszy atmosfera wzajemnego zainteresowania i życzliwości. Jak pisze Anna Wyka: „Kontakt badawczy próbuje się budować na wzór opartej

${ }^{3}$ Warto nadmienić, że przedmiotem dyskusji badaczy jest kwestia ewentualnej gratyfikacji finansowej badanych (por. Surmiak, 2016).

${ }^{4}$ Doświadczenia własne jednej z autorek opracowania potwierdzają to dążenie do „bycia użytecznym” i ,,pomocnym” przez badanych. Badani przez nią skazani, zaintrygowani formułą badania (wywiad biograficzny i atmosfera przypominająca „codzienną rozmowę”, spotkanie dwóch osób zainteresowanych sobą i życzliwie do siebie nastawionych) starali się zaspokoić ciekawość badaczki, poruszając wiele wątków i rekonstruując wydarzenia, których do tej pory nikomu nie wyjawiali. Trwające czasem kilka godzin wywiady kończyły się nie raz sformułowaniami typu: Mam nadzieję, że pani pomogłem; Chciatbym, aby się historia mojego życia na coś przydała (zob. Szczepanik, 2015). 
na wzajemności »zwykłej relacji międzyludzkiej«. Porzuca się »hermeneutykę podejrzliwości«, którą zastępuje właśnie otwarta wymiana oparta na umowie, zaufaniu i szacunku wzajemnym. Badanie jako całość staje się »wspólną drogą«, w której badani »znają swoje życie, my mamy swoje dyspozycje«, badani "znają teren «, a badacze »mają przewodnika«" (Wyka, 1990, s. 165-166).

Nawet jednak najbardziej idealistyczne przesłanki, które leżą u podstaw zgody osób do badań, nie będą stanowić sukcesu, jeśli naukowiec w odpowiedni sposób nie zachęci oraz nie stworzy warunków dla badania. Ponadto w praktyce nie zdarza się, że osoba sama zgłasza się do badacza jakościowego z prośbą, by objął badaniem ją i problemy życiowe będące udziałem grupy, którą reprezentuje. To badacz dociera do potencjalnych uczestników badań, zachęca i zaprasza do udziału w swoim projekcie i to on daje określone gwarancje. Można więc powiedzieć, że w odróżnieniu od pacjenta, który zgłasza się do psychoterapeuty, badany jest osobą, którą naukowiec prosi o pomoc. Naukowiec wkracza (jest zaproszony), a czasami nawet wkrada się w prywatne życie osoby badanej. Staje się gościem badanego (nawet jeśli jest jedynie słuchaczem opowieści o życiu). Doskonale problemy te opisuje Horolets (2016) i stawia pytania o to, w jakim stopniu badacz może „rozgościć się” w terenie (także: biografii badanego) i jak dalece może być posunięta jego lojalność wobec uczestników badań. To, co istotne z punktu widzenia rozważań podjętych $\mathrm{w}$ opracowaniu, to jednak nie odpowiedź na pytanie o granice gościnności, ale o jej konsekwencje.

Jeśli chodzi o Horolets (2016, s. 60), to proponuje ona, by badacza określić raczej mianem „,złego gościa” niż „gościa po prostu”. Goszczenie badacza przez badanego przypomina bowiem bardziej sytuację inwigilacji, dowiadywania się i szpiegowania niż bezkrytycznego przyjmowania wytwarzanego na potrzeby kontaktu wizerunku. Relacja ta obarczona jest z gruntu nierównościami. Dylematy prezentowane $\mathrm{w}$ artykule trafnie ilustruje następująca metafora: badacz „staje się gościem, który nie poddaje się w pełni kontroli gospodarza, ponieważ interesuje się nie tylko tym, co gospodarz jest skłonny wystawić na pokaz, ale także tym, co schowane jest w tylnym pokoju" (tamże, s. 59). To gospodarz zwierza się i to on może (mniej czy bardziej świadomie) wyjawić skrywaną tajemnicę popełnionego przestępstwa, które nie zostało wykryte. Pobyt naukowca w prywatnym świecie badanego nie polega na przyjmowaniu i zawierzeniu, ale na dowiadywaniu, a jego nadrzędnym celem nie jest tworzenie wspólnoty z „gospodarzem” - uczestnikiem badań (tamże, s. 59). Nie jest również jego celem zaprzyjaźnienie się - choć budowana przez niego atmosfera, wnikanie w głęboko skrywane niekiedy zakamarki prywatnego życia innych osób powodują, że tworzy się specyficzna bliskość między badanym i badaczem. Pojawia 
się problem granic tej bliskości - zaprzyjaźniania się i rezultatów tego zjawiska dla jakości zbieranego materiału empirycznego, jego analizy i interpretacji (por. Fatyga, 2013; Surmiak, 2016). Autentyczność i szczerość owej bliskości da się zakwestionować, zwłaszcza gdy uświadomimy sobie cel badacza: jest nim przede wszystkim doprowadzenie do sytuacji, by otrzymać od badanego pewne dobra niematerialne. Są nimi informacje, wiedza, zrekonstruowane doświadczenia, przeżycia emocjonalne itp. Co więcej, badacz robi z pozyskanych dóbr określony pożytek. Jak trafnie ujmuje to Horolets (2016, s. 59): „,w polu naukowym - z daleka od domu »gospodarzy«, czasami w niezrozumiałym dla uczestników badań języku".

\section{Podsumowanie}

Biorąc pod uwagę nasze dotychczasowe ustalenia, można zaryzykować stwierdzenie, że uczestnik badań jakościowych sporo ryzykuje. Nigdy nie ma pewności co do tego, co zrobi z danymi naukowiec, jak je wykorzysta, komu przekaże i w końcu - jak je opisze, w jakiej formie opublikuje oraz kogo one zainteresują. Zresztą - jak już pisaliśmy - mimo najlepszych starań naukowca dane pochodzące zwłaszcza z wywiadów biograficznych są trudne do całkowitego „ukrycia", a niektóre fakty z życia badanych łatwe do zidentyfikowania.

Nakreślone w tytule opracowania „obietnice bez pokrycia” można odnieść do wielu sytuacji, z których każda nacechowana jest specyficznymi sprzecznościami.

Jeśli badacz podąża za zaleceniami etycznymi, to powinien poinformować badanego o tym, że w razie stwierdzenia przestępstw (określonych w konkretnych zapisach prawa) będzie musiał powiadomić o tym organy ścigania. W rezultacie badacz zachęca badanego do maksymalnego otwarcia się, a jednocześnie uprzedza go, by nadto się nie otwierał, by miał świadomość konsekwencji utraty kontroli wypowiedzi i przekroczenia pewnych granic szczerości. Można przypuszczać, że podobna sytuacja nacechowana jest paradoksem i nie pozostanie bez wpływu na mozolnie budowaną przez badacza atmosferę poufności i klimat pełnego otwarcia się. Poinformowanie o ryzyku „doniesienia” to $\mathrm{w}$ istocie uniemożliwienie zbudowania optymalnej relacji właściwie na jej początku, zanim ona zacznie być tworzona.

Badany otrzymuje komunikaty pełne sprzeczności - gwarancję dyskrecji, życzliwości i otwartości oraz groźbę „doniesienia” jednocześnie. Sytuacja taka powodować może (zrozumiałą) dezorientację co do rzeczywistych zamiarów naukowca, który pragnie wniknąć w osobiste zakamarki czyjegoś życia. W isto- 
cie gwarancja o dyskrecji staje się obietnicą bez pokrycia, a bezstronny i życzliwy badacz przeobraża się w funkcjonariusza społecznego, który kieruje się własnym interesem i dlatego jedynie na potrzeby trwania badania przybiera miano gościa.

Warto również postawić pytanie: komu - czemu w rzeczywistości sprzyjają określone procedury prawno-etyczne? Przykładowo, pozyskiwanie zgody pisemnej od badanych stanowi potwierdzenie, że badany został poinformowany o celu badania oraz o tym, że w każdej chwili może z niego zrezygnować bez podania przyczyn. Czyj interes jest jednakże chroniony bardziej? Naukowiec zyskuje poświadczenie, że zastosował określone procedury natury formalno-etycznej. Badany natomiast może mieć wrażenie, że składając deklarację pisemną o zgodzie na udział w badaniach, podpisuje w rzeczywistości „paragraf" o poświadczeniu prawdy, a co więcej, dokumentuje bezpowrotnie swoje doświadczenia i traci drogę odwrotu (tj. zaprzeczenia podanym informacjom $\mathrm{w}$ razie potrzeby). Zwłaszcza w przypadku badań wśród osób łamiących normy obyczajowe i przestępców nasuwa to bardzo jednoznaczne skojarzenie podpisywania się pod złożonymi zeznaniami np. po przesłuchaniu przez policję. Nie jest to wniosek hipotetyczny, ale znajduje swoje potwierdzenie w praktyce badawczej. Doświadczenia swoje w tym zakresie opisują badacze osób świadczących usługi seksualne i skazanych (Niedbalski, Ślęzak, 2017; Nowak, 2011). Analizując tę procedurę formalno-etyczną, Nowak $(2011)^{5}$ wprost przyznał, że uniemożliwiło mu to realizację badań $\mathrm{w}$ więzieniach. Co prawda skazani byli życzliwie do niego nastawieni i chcieli rozmawiać otwarcie o swojej aktywności przestępczej, ale tracili ten zapał, gdy wymogiem stawała się deklaracja pisemnej zgody na udział w badaniach. Na podobne problemy natknęła się Sikorska (2017), która badała mężczyzn przebywających w zakładzie karnym dorosłe dzieci skazanych rodziców ${ }^{6}$.

Jak wykazaliśmy, zgodnie z obowiązującymi rozwiązaniami prawnymi badacz, który pozyska informację o popełnionym przestępstwie opisanym w art.

${ }^{5}$ Autor podejmuje rozważania na ten temat, przywołując ustalenia i standardy kodeksów kryminologicznych w innych krajach. Formułuje przypuszczenie, że wprowadzenie wymogu pisemnej zgody w Polsce spowoduje liczbę fałszywych odpowiedzi udzielanych w badaniu. W przypadku badań realizowanych w instytucjach o charakterze totalnym problem ten jest o tyle ważny, że rzeczywista zgoda i dobrowolność udziału w badaniach jest dyskusyjna (por. Szczepanik, 2017; Dzieduszyński, 2017).

${ }^{6}$ Sikorska pozyskiwała poczatkowo pisemne zgody od badanych, ale obserwacja ich reakcji spowodowała, że podjęła decyzję o rezygnacji z takiej formuły (informacje pozyskane z dyskusji w ramach zebrania naukowego na Wydziale Nauk o Wychowaniu UŁ). 
240 k.k., jest zobligowany do poinformowania o tym fakcie organy ścigania. Niedopełnienie tego obowiązku jest określane w kodeksie karnym jako występek przeciwko wymiarowi sprawiedliwości i zagrożone karą pozbawienia wolności. Pozostaje pytanie otwarte: jak wielu badaczy nie zdaje sobie z tego faktu sprawy i jak wielu z nich może nieświadomie łamać przepisy prawa, kierując się zasadą bezwzględnego dobra badanego? Jak wielu badaczy i psychoterapeutów nie zdaje sobie sprawy z tego, że zakres przestępstw, które obowiązkowo trzeba zgłaszać do organów ścigania, został rozszerzony w 2017 roku? Obietnica zachowania poufności przekazywanych danych stoi w sprzeczności z przepisami prawa, gdy badany przyzna się do zabójstwa, określonych przez ustawodawcę rodzajów gwałtu, czynów pedofilnych lub innego czynu opisanego w art. 240 k.k. Jeśli badacz nie informuje o tym, że w szczególnych sytuacjach badany jest narażony na ujawnienie określonych treści wywiadu organom ścigania, narusza etykę prowadzenia badań naukowych. Zatajenie przed badanym tego faktu niektórzy naukowcy określają mianem chęci wkupienia się w łaski badanego i uzyskania od niego większej ilości szczerych informacji. Jak stwierdzają Brzeziński i Toeplitz-Winiewska (2008), takie działanie z etycznego punktu widzenia jest niedopuszczalne. $Z$ drugiej strony to właśnie odkrywanie „sekretnego życia" i skrywanych tajemnic przez badacza daje mu możliwości pełniejszego poznania i zrozumienia świata społecznego badanych. Poinformowanie badanego o ryzyku konieczności zgłoszenia informacji o przestępstwie może spowodować, że będzie on unikał wszystkich wrażliwych tematów związanych np. z łamaniem norm - nie tylko prawnych, ale i obyczajowych oraz eksponował jedynie ,ja idealne" z punktu widzenia prawa.

Dylematy związane ze złamaniem obietnicy poufności w przypadkach, o których piszemy w artykule, wiążą się także z konsekwencjami dla kolejnych badań naukowych. Badacz, podobnie jak psychoterapeuta, powinien pamiętać, że jedno odtajnienie informacji dotyczących życia osoby badanej może sprawić, że także i inne osoby z jej otoczenia już nigdy nie wyrażą zgody na udział w jakichkolwiek badaniach naukowych. Sytuacja taka stanowi bowiem wyraźny sygnał: wbrew składanym deklaracjom naukowiec, psychoterapeuta nie jest w stanie zapewnić osobom badanym/pacjentom anonimowości i poufności (Brzeziński, 2009). Dla potencjalnych badanych, którzy mają świadomość prawnych konsekwencji swojej szczerości i otwartości, przyrzeczenia nawet najbardziej wyszukanych zabezpieczeń danych pozyskanych w trakcie badań mogą jawić się jako obietnice bez pokrycia. 


\section{Bibliografia}

Andrejuk K. (2014), Prawne i etyczne aspekty archiwizacji badań socjologicznych, „Studia Socjologiczne", nr 3, s. 203-210.

Bielska B. (2016), Praktyki ukrywania. O pułapkach, pokusach i pożytkach z badań niejawnych, „Przegląd Socjologii Jakościowej”, t. 12, nr 3, s. 70-87.

Bond T. (2015), Standards and Ethics for Counselling in Action, Sage, Los Angeles - London - New Delhi - Singapore - Washington DC.

Brzeziński J.M., Toeplitz-Winiewska M. (2008), Etyczne problemy działalności praktycznej, edukacyjnej i naukowej psychologa, w: J. Strelau, D. Doliński (red.), Psychologia. Podręcznik akademicki, t. 1, Gdańskie Wydawnictwo Psychologiczne, Gdańsk.

Brzeziński J.M. (2009), Psycholog wobec osób uczestniczacych w badaniach psychologicznych - między poprawnościa metodologiczna a poprawnościa etyczna, w: J.M. Brzeziński, B. Chyrowicz, W. Poznaniak, M. Toeplitz-Winiewska (red.), Etyka zawodu psychologa, Wydawnictwo Naukowe PWN, Warszawa.

Chomczyński P. (2006), Wybrane problemy etyczne w badaniach. Obserwacja uczestniczaca ukryta, „Przegląd Socjologii Jakościowej”, nr 2.1, s. 68-87.

Chomczyński P. (2014), Działania wychowanków schronisk dla nieletnich i zakładów poprawczych, Wydawnictwo Uniwersytetu Łódzkiego, Łódź.

Cymbrowski B., Rancew-Sikora D. (2016), Od redaktorów: Dylematy etyczne i ryzyko w badaniach terenowych, „Przegląd Socjologii Jakościowej”, nr 12.3, s. 6-21.

Department of Health (2003), Confidentiality: NHS Code of Practice, Department of Health, London. (Dostęp: 5.04.2017)w: https://www.gov.uk/government/uploads/system/uploads/attachment_data/file/200146/Confidentiality___NHS_Code_of_Practice.pdf.

Dzieduszyński P. (2017), Sytuacja odrzucenia jako dominujacy problem wychowanków domów dziecka, w: P. Dzieduszyński (red.), Naznaczeni, odrzucani i dyskryminowani w badaniach naukowych i praktyce wychowawczej. Ujęcie interdyscyplinarne, Wydawnictwo WSBiNoZ w Łodzi, Łódź.

Fatyga B. (2013), Praktyki badawcze, Instytut Stosowanych Nauk Społecznych UW, Warszawa.

Galewicz W. (2009), O etyce badań naukowych, „Diametros”, nr 19, s. 48-57, DOI: 10.13153/diam.19.2009.330.

Gardocki L. (1998), Prawo karne, C.H. Beck, Warszawa.

Golczyńska-Grondas A., Grondas M. (2013), Badania biograficzne a psychoterapia. Kilka 


\section{METODY ZBIERANIA I ANALIZY DANYCH W BADANIACH EDUKACYJNYCH}

uwag o terapeutycznych aspektach socjologicznych wywiadów biograficznych, „Przegląd Socjologii Jakościowej”, t. 4.9, s. 28-49.

Horolets A. (2016), Badacz jako gość, „Przegląd Socjologii Jakościowej”, nr. 12.3, s. 54-69.

Kaźmierska K. (2004), Wywiad narracyjny jako jedna z metod w badaniach biograficznych, „Przegląd Socjologiczny”, nr 1, s. 71-95.

Kaźmierska K. (2014), Autobiograficzny wywiad narracyjny - kwestie etyczne i metodologiczne w kontekście archiwizacji narracji, „Studia Socjologiczne”, nr 3, s. 221-238.

Kiembłowski P. (2005), Wywiad psychologiczny z ofiara przemocy seksualnej, w: K. Stemplewska-Żakowicz, K. Krejtz (red.), Wywiad psychologiczny. Wywiad w różnych kontekstach praktycznych, t. 3, Pracownia Testów Psychologicznych PTP, Warszawa.

Kleszcz I. (2004), Wykorzystanie ukrytej obserwacji uczestniczącej w badaniu stylu życia szarej strefy, „Kultura i Społeczeństwo”, nr 2, s. 189-202.

Kodeks karny (1997), Dz.U. Nr 88, poz. 553 ze zmianami.

Kodeks postępowania karnego (1997), Dz.U. Nr 89, poz. 555 ze zmianami.

Konecki K., Chomczyński P., Kacperczyk A., Byczkowska D. (2012), Słownik socjologii jakościowej, Difin, Warszawa.

Konstytucja Rzeczpospolitej Polskiej (1997), Dz.U. Nr 78, poz. 483.

Kuźma I. (red.) (2013), Tematy trudne. Sytuacje badawcze, Wydawnictwo Uniwersytetu Łódzkiego, Łódź.

Męcfal S. (2016), Badacz zjawisk trudno dostępnych w terenie - kwestie etyczne, praktyczne i metodologiczne, „Przegląd Socjologii Jakościowej”, nr 12.3, s. 88-100.

Miszewski K. (2007), Kiedy badacz jest tajnym agentem. O postrzeganiu niejawnej obserwacji uczestniczacej jako etycznie problematycznej, metodach badań ilościowych, zakulisowych wymiarach życia społecznego i ich związu ze wszystkim tym, o czym przed chwila, ,Przegląd Socjologii Jakościowej”, t. 3.2, s. 33-62.

Niedbalski J. (2013), Żyć i pracować w domu pomocy społecznej. Socjologiczne studium interakcji personelu z upośledzonymi umysłowo podopiecznymi, Wydawnictwo Uniwersytetu Łódzkiego, Łódź.

Niedbalski J., Ślęzak I. (2017), Etyczne, metodologiczne i techniczne aspekty upowszechniania $i$ archiwizacji danych jakościowych, ,Roczniki Nauk Społecznych”, t. 44.2, s. 223-241, DOI: 10.18290/rns.2016.8(44).2-11.

Nowak P. (2011), Etyka badań naukowych nad przestępstwem, „Rocznik Pedagogiczny. Edukacja, Wychowanie, Resocjalizacja, (Dostęp: 30.07.2017), w: http://kn.edu.pl/pdf/ nowak.pdf. 
Nowicka E. (2016), Antropolog wobec innych $i$ wobec siebie. Niektóre problemy etyczne uprawiania antropologii, „Przegląd Socjologii Jakościowej”, t. 12.3, s. 40-53.

Polska Akademia Nauk (2012), Kodeks etyki pracownika naukowego. Załacznik do uchwaty nr 10/2012 Zgromadzenia Ogólnego PAN z dnia 13 grudnia 2012 r. (Dostęp 4.02.2016 r.), http://www.instytucja.pan.pl/images/stories/pliki/Komisja_ds_Etyki_Nauce/dokumenty/Kodeks_etyki_pracownika_naukowego.pdf〉.

Polskie Towarzystwo Psychologiczne (1991), Kodeks etyczno-zawodowy psychologa, (Dostęp: 5.04.2017), http://www.ptp.org.pl/modules.php?name=News\&file=article$\& \operatorname{sid}=29$,

Polskie Towarzystwo Socjologiczne (2012), Kodeks etyki socjologa, (Dostęp: 27.06.2017), http://socjolekt.uni.opole.pl/wpcontent/uploads/2012/04/PolskieTowarzystwoSocjologiczne KodeksEtykiSocjologa.pdf.

Prawo prasowe (1984), Dz.U. Nr 5, poz. 24.

Rancew-Sikora D., Cymbrowski B. (2016), W stronę socjologicznego ujęcia etyki badań naukowych, „Przegląd Socjologii Jakościowej”, t. 12.3, s. 22-39.

Sąd Apelacyjny (2010), Wyrok Sądu Apelacyjnego w Krakowie z dnia 4.11.2010, II AKa $182 / 10$.

Schütze F. (1992), Pressure and Guilt: War Experiences of a Young German Soldier and their Biographical Implications. Part 1 and 2, „International Sociology”, t. 7(2/3), s. 187-208, 347-367, DOI: 10.1177/026858092007002005.

Sikorska A. (2017), , Sieroty wymiaru sprawiedliwości” w świetle koncepcji naznaczania społecznego, w: P. Dzieduszyński (red.), Naznaczeni, odrzucani i dyskryminowani w badaniach naukowych i praktyce wychowawczej. Ujęcie interdyscyplinarne, Wydawnictwo WSBiNoZ w Łodzi, Łódź.

Straczuk J., Filipkowski P. (2014), Archiwizacja danych jakościowych. Wprowadzenie, „Studia Socjologiczne", nr 3, s. 161-166.

Surmiak A. (2010), Zaangażowany antropolog. O potrzebie granic, „Prace Etnograficzne”, nr 38, s. 179-186.

Surmiak A. (2016), Wybrane problemy etyczne w naukowych badaniach na zlecenie. Refleksje etnografki, „Przegląd Socjologii Jakościowej”, t. 8.31, s. 120-134.

Szczepanik R. (2015), Stawanie się recydywistą. Kariery instytucjonalne osób powracajacych do przestępczości, Wydawnictwo Uniwersytetu Łódzkiego, Łódź.

Szczepanik R. (2017), Status badacza „jakościowego”w środowisku osób naznaczonych i wykluczonych społecznie, w: P. Dzieduszyński (red.), Naznaczeni, odrzucani i dyskry- 


\section{METODY ZBIERANIA I ANALIZY DANYCH W BADANIACH EDUKACYJNYCH}

minowani w badaniach naukowych i praktyce wychowawczej. Ujęcie interdyscyplinarne, Wydawnictwo WSBiNoZ w Łodzi, Łodź.

Szczepanik R., Siebert S. (2016), The Triple Bind of Narration: Fritz Schütze's Biographical Interview in Prison Research and Beyond, „Sociology”, t. 50.2, s. 285-300, DOI: $10.1177 / 0038038515570145$.

Ślęzak I. (2013), Refleksje nad zagadnieniem piętna w relacjach badacza i badanych na podstawie wywiadów z kobietami świadczacymi ustugi seksualne, „Nauka i Szkolnictwo Wyższe", nr 1, s. 153-166.

Toeplitz-Winiewska M. (2009a), Podstawowe zasady, które powinny być respektowane przez psychologa, w: J.M. Brzeziński, B. Chyrowicz, W. Poznaniak, M. Toeplitz-Winiewska (red.), Etyka zawodu psychologa, Wydawnictwo Naukowe PWN, Warszawa.

Toeplitz-Winiewska M. (2009b), Udzielanie pomocy psychologicznej, w: J.M. Brzeziński, B. Chyrowicz, W. Poznaniak, M. Toeplitz-Winiewska (red.), Etyka zawodu psychologa, Wydawnictwo Naukowe PWN, Warszawa.

Ustawa o ochronie zdrowia psychicznego (1994), Dz.U. Nr 111, poz. 535.

Ustawa o przeciwdziałaniu przemocy w rodzinie (2005), Dz.U. Nr 18, poz. 1493.

Ustawa o zawodzie lekarza (2002), Dz.U. Nr 21, poz. 204.

World Medical Association (1964), Declaration of Helsinki. Human Experimentation. Code of Ethics of the World Medical Association, [Dostęp: 27.06.2017] https://www.ncbi. nlm.nih.gov/pmc/articles/PMC1816102/pdf/brmedj02559-0071.pdf.

Wyka A. (1990), Ku nowym wzorom badań społecznych w Polsce. Cechy badań jakościowych w ostatnich latach, „Kultura i Społeczeństwo”, nr 1, s. 161-173.

Wyka A. (1993), Badacz społeczny wobec doświadczenia, Wydawnictwo IFiS PAN,Warszawa.

Witkowski M. (2016), Zanim doprowadzisz do pogromu: między doświadczeniem etnograficznym z badań terenowych $w$ społecznościach romskich a antropologicznym tekstem naukowym, „Przegląd Socjologii Jakościowej”, t. 12.3, s. 102-119.

Żylińska J. (2015), Prawny obowiązek zawiadomienia o niektórych przestęstwach (art. 240 k.k.), „Prokuratura i Prawo”, nr 10, s. 47-62. 